\title{
Magnesium Potassium Phosphate Compound for Immobilization of Radioactive Waste Containing Actinide and Rare Earth Elements
}

\author{
Sergey E. Vinokurov *, Svetlana A. Kulikova and Boris F. Myasoedov \\ Vernadsky Institute of Geochemistry and Analytical Chemistry, Russian Academy of Sciences, 19 Kosygin st., \\ Moscow 119991, Russia; kulikova.sveta92@mail.ru (S.A.K.); bf@geokhi.ru (B.F.M.) \\ * Correspondence: vinokurov.geokhi@gmail.com; Tel.: +7-495-939-7007
}

Received: 17 May 2018; Accepted: 5 June 2018; Published: 8 June 2018

\begin{abstract}
The problem of effective immobilization of liquid radioactive waste (LRW) is key to the successful development of nuclear energy. The possibility of using the magnesium potassium phosphate (MKP) compound for LRW immobilization on the example of nitric acid solutions containing actinides and rare earth elements (REE), including high level waste (HLW) surrogate solution, is considered in the research work. Under the study of phase composition and structure of the MKP compounds that is obtained by the XRD and SEM methods, it was established that the compounds are composed of crystalline phases-analogues of natural phosphate minerals (struvite, metaankoleite). The hydrolytic stability of the compounds was determined according to the semi-dynamic test GOST R 52126-2003. Low leaching rates of radionuclides from the compound are established, including a differential leaching rate of ${ }^{239} \mathrm{Pu}$ and ${ }^{241} \mathrm{Am}-3.5 \times 10^{-7}$ and $5.3 \times 10^{-7} \mathrm{~g} /\left(\mathrm{cm}^{2}\right.$.day $)$. As a result of the research work, it was concluded that the MKP compound is promising for LRW immobilization and can become an alternative material combining the advantages of easy implementation of the technology, like cementation and the high physical and chemical stability corresponding to a glass-like compound.
\end{abstract}

Keywords: magnesium potassium phosphate compound; actinides; rare earth elements; uranium; plutonium; americium; lanthanum; neodymium; immobilization; leaching

\section{Introduction}

Long-term controlled storage or disposal is one of the key stages of the liquid radioactive waste (LRW) management in terms of radiation safety. The preparation of the LRW for this stage involves the transfer of waste into a stable solidified form using preserving matrices [1,2]. Cementation has found wide use in the nuclear industry for radioactive waste (RW) management of low and intermediate activity levels, in spite of significant disadvantages of the method, especially the relatively low degree of incorporation of waste salts, as well as low hydrolytic stability and frost resistance of cement compound. Vitrification is currently the only high level waste (HLW) management technology that is applied in industry [3]. The disadvantages of the method are low chemical and crystallization resistance of the glass at elevated temperatures, as well as the need to use expensive high temperature melters, the liquidation of which, after the end of a relatively short technical lifetime, represents an unresolved radioecological problem.

Ceramic materials [4], and especially synthetic analogues of natural phosphate minerals $[5,6]$, are considered as an alternative to cement and glass for the immobilization of RW, primarily obtained after the reprocessing of spent nuclear fuel (SNF) and containing long-lived isotopes of highly toxic actinides and rare earth elements (REE). 
The mineral-like phosphate materials that were obtained at room temperature in aqueous solution by chemical interaction, as a rule, between metal (II) oxides ( $\mathrm{MgO}, \mathrm{ZnO}, \mathrm{FeO}, \mathrm{CaO}$ ) and orthophosphoric acid $\left(\mathrm{H}_{3} \mathrm{PO}_{4}\right)$ or its derivatives (for example, (di) hydrogenphosphates of metals (I) or ammonium) $[7,8]$ are of particular interest.

Previously, we and other researchers demonstrated [9-16] that magnesium potassium phosphate $(\mathrm{MKP})$ compound based on the $\mathrm{MgKPO}_{4} \times 6 \mathrm{H}_{2} \mathrm{O}$ matrix obtained as a result of the reaction (1), which is an analog of the natural mineral K-struvite [17], is a promising low-temperature material for the immobilization of various RW types.

$$
\mathrm{MgO}+\mathrm{KH}_{2} \mathrm{PO}_{4}+5 \mathrm{H}_{2} \mathrm{O} \rightarrow \mathrm{MgKPO}_{4} \times 6 \mathrm{H}_{2} \mathrm{O}
$$

This method of RW management combines versatility, equipment simplicity and economic efficiency similar cementation, and the obtained MKP compound has a high physical and chemical stability.

The practical use possibility of MKP compound in RW management has to be explained in the context of reliability under the long storage of hazardous RW components mainly highly toxic plutonium and minor actinides, as well as REE, whose content is about half the content of all the metals in HLW. It should also be noted that, although uranium is maximally recovered from solutions during SNF reprocessing for its reuse in the fuel cycle, the residual uranium content (including isotopes $\mathrm{U}-232,235,236,238$ ) in HLW is about $3 \mathrm{~g} \cdot \mathrm{L}^{-1}$. Thus, information on the behavior of uranium during immobilization in the MKP compound also has scientific interest.

The data on the phase composition, structure, and hydrolytic stability of synthesized MKP compounds containing uranium, plutonium, americium, and REE (on the example, lanthanum and neodymium) are presented in this article.

\section{Materials and Methods}

The experiments were performed in the glove box (PERERABOTKA, Dzerzhinsk, Russia). The chemicals used in the experiments were of no less than chemically pure grade. Samples of MKP compounds were prepared, according to the procedure previously given in reference [10]. For study, the forms of location and behavior during leaching of uranium and REE by the example of lanthanum in the MKP compound, concentrated aqueous solutions of their nitrates with a metal concentration 228.3 and $242.4 \mathrm{~g} \cdot \mathrm{L}^{-1}$, respectively, were solidified.

The hydrolytic stability of MKP compound to the leaching of actinides and neodymium as a simulator of the REE group was carried out after the solidification of the HLW surrogate solution of 1000 MW water-water energetic reactor (WWER-1000). The HLW surrogate solution was prepared by dissolving the metal nitrates in an aqueous solution of nitric acid, molybdenum was added in the form of $\mathrm{MoO}_{3}$ (Table 1). Preparation of the surrogate solution to solidification was carried out by neutralizing it to $\mathrm{pH} 8.0 \pm 0.1$ with sodium hydroxide solution at concentration $15.0 \pm 0.1 \mathrm{~mol} \cdot \mathrm{L}^{-1}$.

Table 1. Characteristics of high level waste (HLW) surrogate solution.

\begin{tabular}{|c|c|c|c|c|}
\hline $\begin{array}{l}\text { Specific Activity of } \\
\text { Actinides }\left(\mathrm{Bq} \cdot \mathrm{L}^{-1}\right)\end{array}$ & Metal Content $\left(\mathrm{g} \cdot \mathrm{L}^{-1}\right)$ & $\mathrm{HNO}_{3}$ Content $\left(\mathrm{mol} \cdot \mathrm{L}^{-1}\right)$ & Density $\left(g \cdot \mathrm{L}^{-1}\right)$ & Salt Content $\left(\mathrm{g} \cdot \mathrm{L}^{-1}\right)$ \\
\hline $\begin{array}{c}{ }^{239} \mathrm{Pu}-3.8 \times 10^{8} \\
{ }^{241} \mathrm{Am}-5.2 \times 10^{7}\end{array}$ & $\begin{array}{c}\mathrm{Na}-13.3 ; \mathrm{Sr}-3.9 ; \mathrm{Zr}-7.6 \\
\mathrm{Mo}-0.9 ; \mathrm{Pd}-5.4 ; \mathrm{Cs}-9.3 \\
\mathrm{Ba}-6.4 ; \mathrm{Nd}-28.8 ; \mathrm{Fe}-1.0 \\
\mathrm{Cr}-2.8 ; \mathrm{Ni}-0.5 ; \mathrm{U}-3.1\end{array}$ & 3.2 & 1210 & 206.6 \\
\hline
\end{tabular}

The phase composition of the prepared MKP compounds was determined by X-ray diffraction (XRD) (Ultima-IV, Rigaku, Tokyo, Japan). The X-ray diffraction data were interpreted using the specialized Jade 6.5 program package (MDI, Livermore, CA, USA) with PDF-2 powder database. 
The structure of samples containing uranium and lanthanum was studied by the scanning electron microscopy (SEM) using microscopes Jeol JSM-6480LV (JEOL, Tokyo, Japan) and LEO Supra 50 VP (LEO Carl Zeiss SMT Ltd, Oberkochen, Germany), respectively. The electron probe microanalysis of the samples was performed using an energy-dispersive analyzer X-MAX 80 (Oxford Instruments plc, Abingdon, England).

The hydrolytic stability of compounds was determined using the semidynamic test, in accordance with GOST R 52126-2003 [18]. Conditions: Monolithic compound $2 \mathrm{~cm} \times 2 \mathrm{~cm} \times 2 \mathrm{~cm}$; leaching agent-bidistilled water ( $\mathrm{pH} 6.6 \pm 0.1$, volume $200 \mathrm{~mL}$ ), temperature $23 \pm 2{ }^{\circ} \mathrm{C}$, periodic replacement of the leaching agent after 1,3,7,10,14, and 21 days, the total duration of the test was limited to 28 days. The content of lanthanum, neodymium, and uranium in solutions after leaching was determined by inductively coupled plasma atomic emission spectrometry (ICP-AES) (iCAP-6500 Duo, Thermo Scientific, Waltham, MA, USA), inductively coupled plasma mass spectrometry (ICP-MS) (X Series2, Thermo Scientific, Waltham, MA, USA), and by spectrophotometry (Cary 100 Scan, Varian, Palo Alto, CA, USA), and the content of ${ }^{239} \mathrm{Pu}$ and ${ }^{241} \mathrm{Am}$-radiometric method with using of the $\alpha$-spectrometer (Alpha Analyst, Canberra, Australia).

The mechanism of leaching of the compound components (lanthanum, neodymium, uranium, plutonium, and americium) from the samples was evaluated according to the model [19], described by the linear relationship of $\log \left(B_{i}\right)$ from $\log (t)$, where $B_{i}$ is the total yield of the element from the compound during contact with water, $\mathrm{mg} \cdot \mathrm{m}^{-2} ; \mathrm{t}$ is the contact time, days. The calculate procedure of $B_{i}$ is given in $[9,20]$. The following mechanisms of element leaching from the compound correspond to various values of the slope in this equation: $>0.65$ - surface dissolution; 0.35-0.65-diffusion transport; $<0.35$ - surface wash off (or a depletion if it is found in the middle or at the end of the test) $[9,10,20-23]$.

\section{Results}

As a result of the performed experiments, the samples of MKP compounds with a density of $1.75 \pm 0.07 \mathrm{~g} \cdot \mathrm{cm}^{-3}$ were prepared. The content of metals in compounds that were obtained under solidification of uranium and lanthanum nitrate solutions was $6.2 \mathrm{wt} \%$ uranium (hereinafter, compound \#1) and $6.7 \mathrm{wt} \%$ lanthanum (hereinafter, compound \#2), respectively. The salt content of the HLW surrogate solution that was obtained under neutralization was $369.5 \mathrm{~g} \cdot \mathrm{L}^{-1}$, and filling of the compound by the salts of neutralized surrogate solution was $12.8 \mathrm{wt} \%$, and the specific activity of ${ }^{239} \mathrm{Pu}$ and ${ }^{241} \mathrm{Am}$ was $1.8 \times 10^{5}$ and $2.4 \times 10^{4} \mathrm{~Bq} \cdot \mathrm{g}^{-1}$ (hereinafter, compound \#3). The content of the components of the MKP compounds is presented in Table 2.

Table 2. Composition of magnesium potassium phosphate (MKP) compounds under study.

\begin{tabular}{ccccc}
\hline \multirow{2}{*}{ Compound } & \multirow{2}{*}{ Liquid Waste (wt \%) } & \multicolumn{3}{c}{ Binders (wt \%) } \\
\cline { 3 - 5 } & & $\mathbf{K H}_{\mathbf{2}} \mathbf{P O}_{\mathbf{4}}$ & $\mathbf{H}_{\mathbf{3}} \mathbf{B O}_{3}$ & $\mathbf{M g O}$ \\
\hline$\# 1$ & 39.5 & 44.2 & 1.5 & 14.8 \\
$\# 2$ & 43.4 & 41.3 & 1.5 & 13.8 \\
$\# 3$ & 41.5 & 42.9 & 1.3 & 14.3 \\
\hline
\end{tabular}

The obtained data on the study of the phase composition and structure of synthesized compounds \#1-3 by XRD and SEM methods are shown in Figures 1 and 2, respectively.

In accordance with GOST R 52126-2003 [18], the differential leaching rates of actinides and REE from synthesized compound \#1-3 during 28 days of contact with water (Figure 3a,c,e) were determined, and the mechanisms of their leaching (Figure $3 b, d, f$, as summarized in Table 3) were estimated. 
(a)

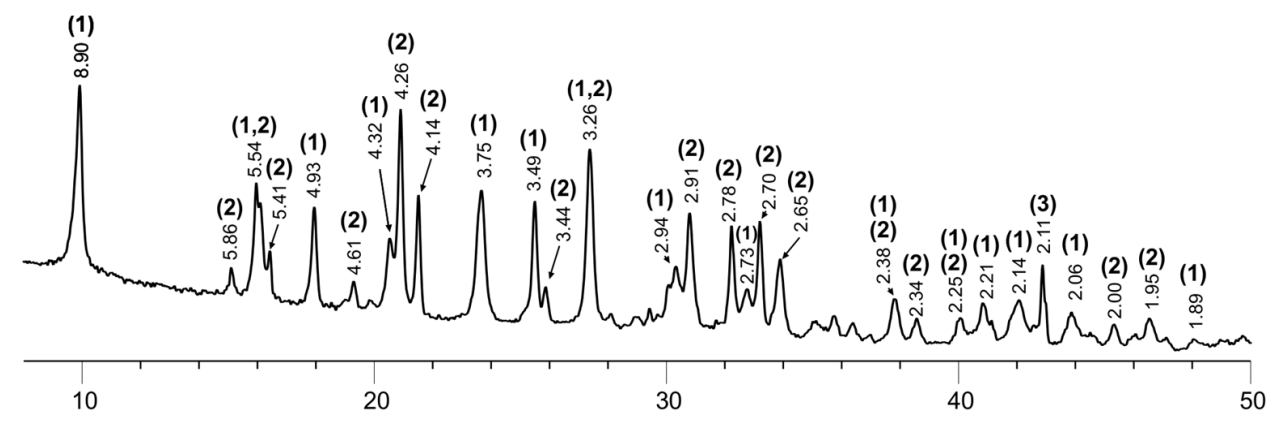

(b)

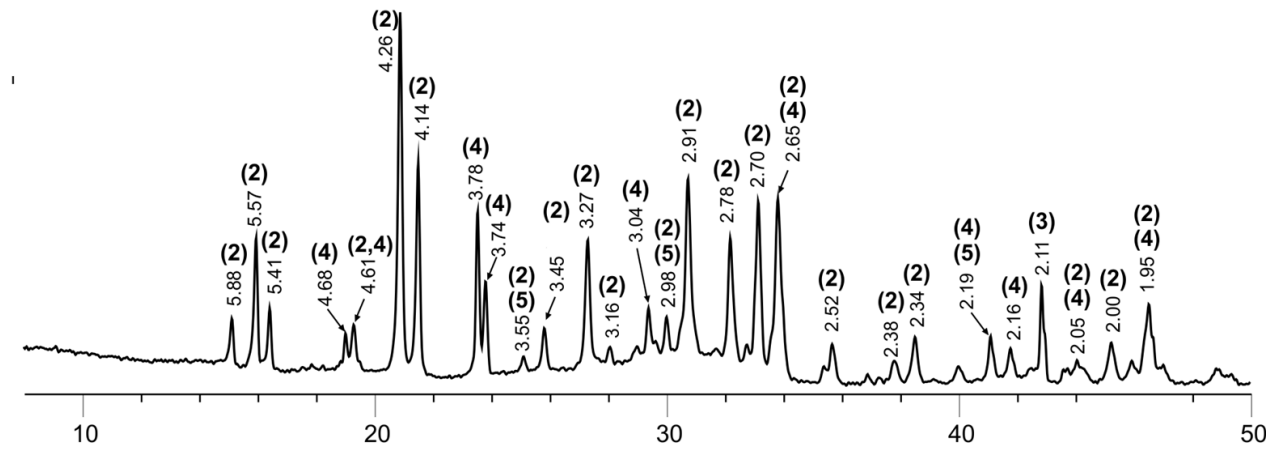

(c)

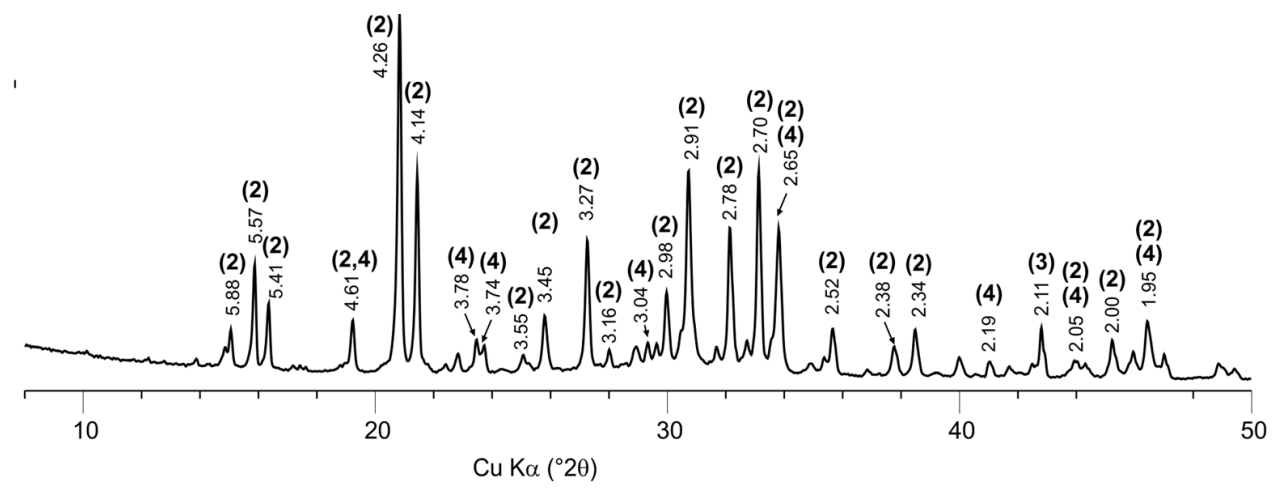

$\left.1-\mathrm{K}_{\left(\mathrm{UO}_{2}\right.}\right) \mathrm{PO}_{4} \times 3 \mathrm{H}_{2} \mathrm{O}$ (metaankoleite); $2-\mathrm{MgKPO}_{4} \times 6 \mathrm{H}_{2} \mathrm{O}$ (K-struvite); $3-\mathrm{MgO}$ (periclase); $4-\mathrm{KNO}_{3}$ (niter); $5-\mathrm{LaPO}_{4} \times 0.5 \mathrm{H}_{2} \mathrm{O}($ rhabdophane- $($ La $))$

Figure 1. X-ray diffraction patterns of the compounds: \#1 (a) and \#2 (b), containing 6.2 wt \% and $6.7 \mathrm{wt} \%$ uranium and lanthanum, respectively, and \#3 (c), obtained by solidification of HLW surrogate solution.

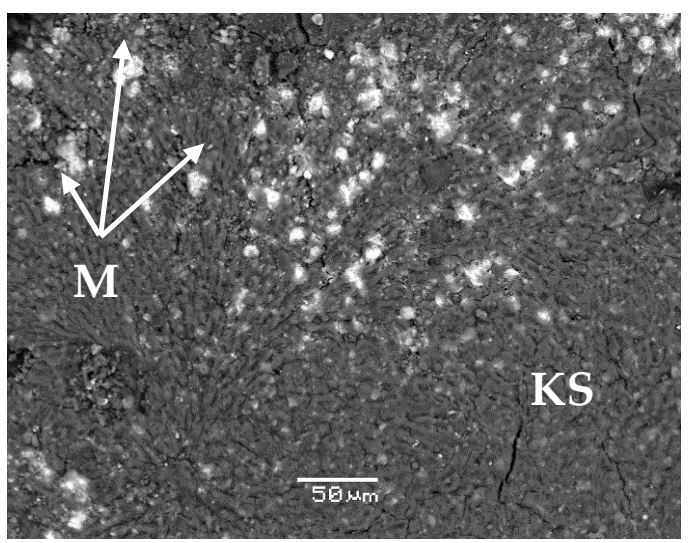

(a)

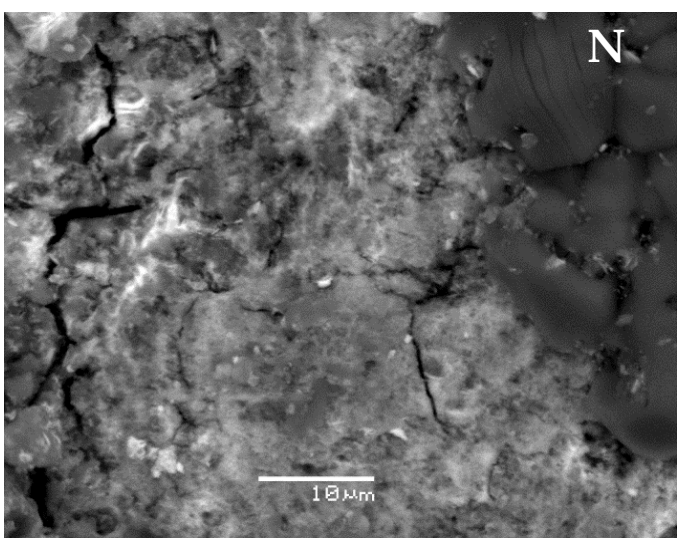

(b)

Figure 2. Cont. 


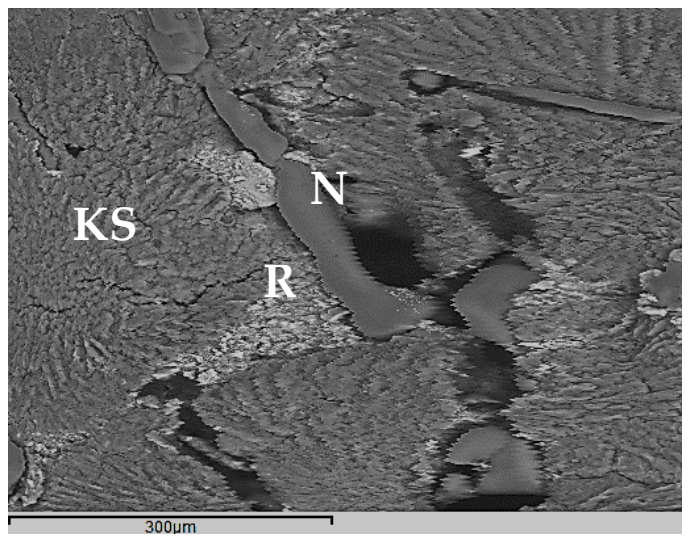

(c)

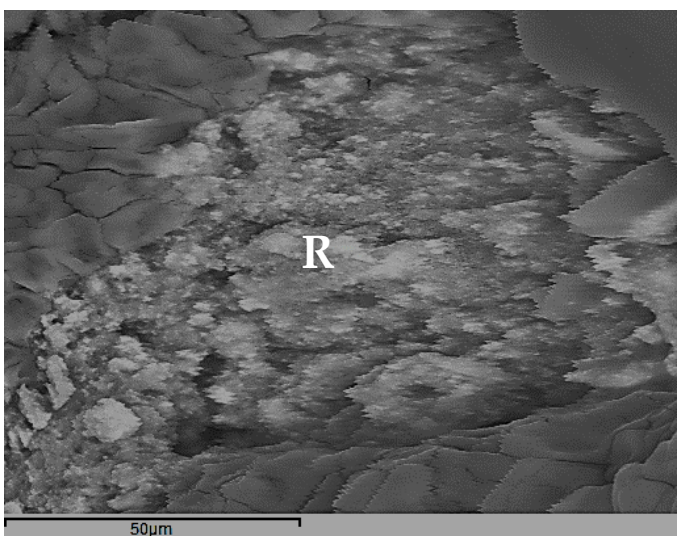

(d)

$M$-metaankoleite; KS - K-struvite; $N$-niter; $R$-rhabdophane-(La)

Figure 2. Scanning electron microscopy (SEM) images of the compounds \#1 (a,b) and \#2 (c,d), containing $6.2 \mathrm{wt} \%$ and $6.7 \mathrm{wt} \%$ uranium and lanthanum, respectively.

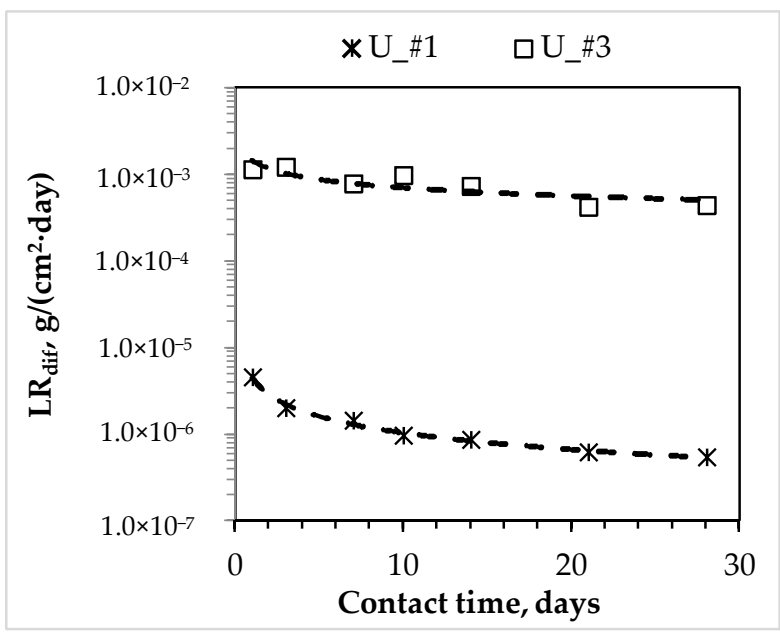

(a)

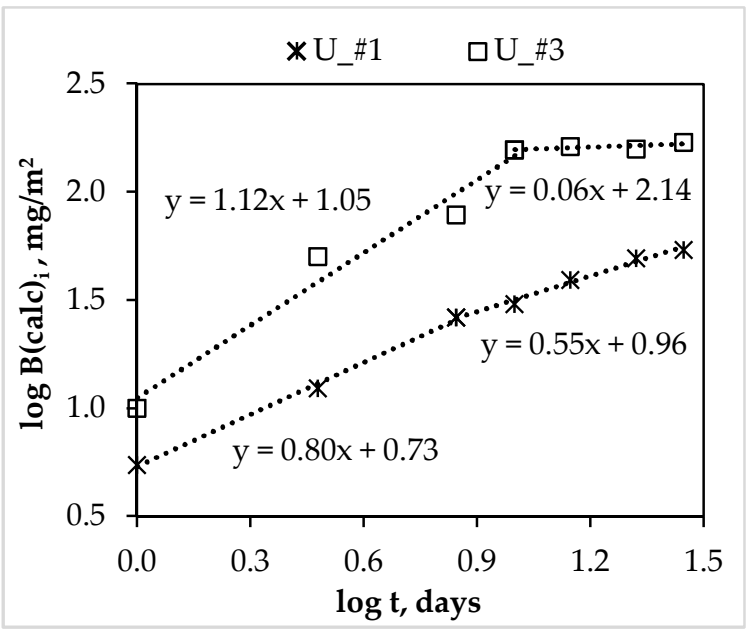

(b)

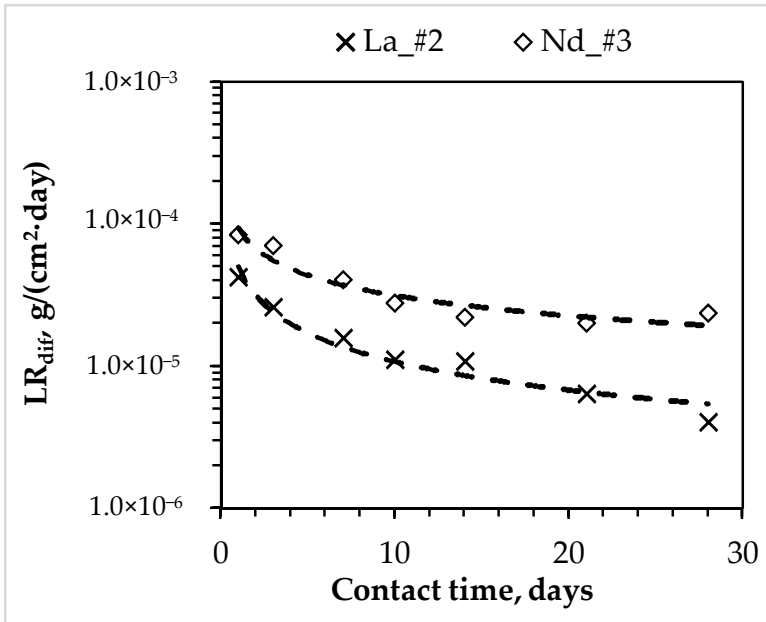

(c)

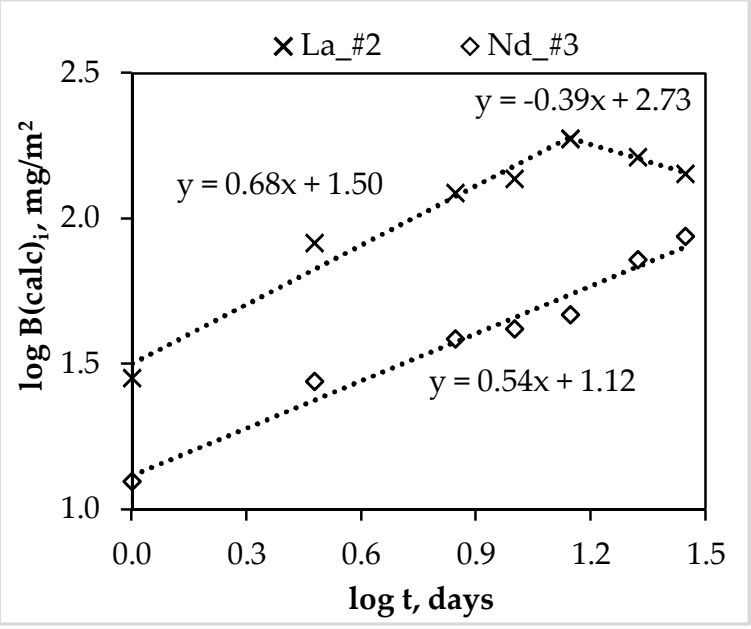

(d)

Figure 3. Cont. 


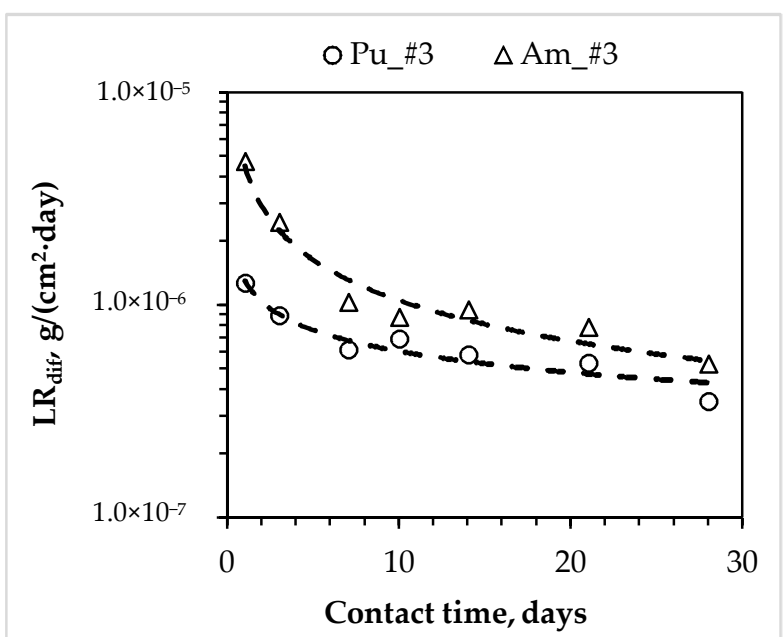

(e)

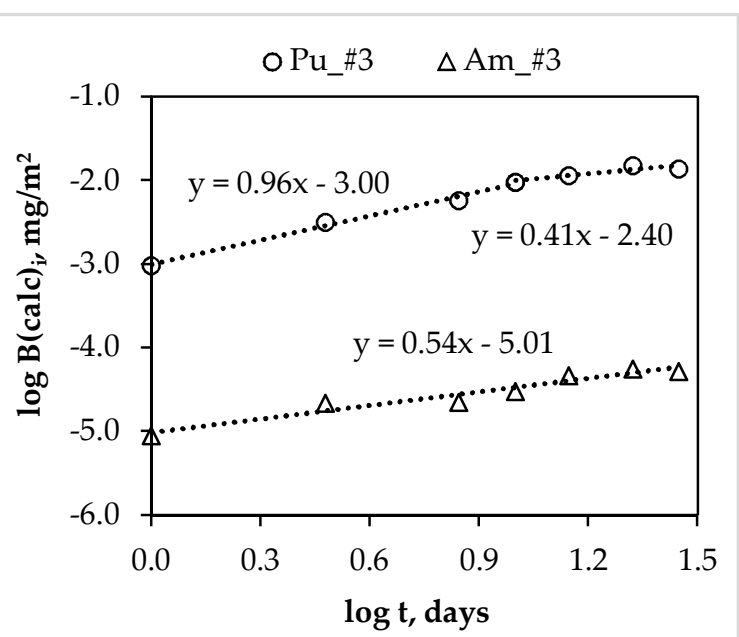

(f)

Figure 3. Dependence of the differential leaching rate $\left(L_{\mathrm{dif}}\right)$ of actinides and rare earth elements (REE) $(\mathbf{a}, \mathbf{c}, \mathbf{e})$ and the logarithmic dependence of their yield $\left(\log \mathrm{B}(\mathrm{calc})_{\mathrm{i}}\right)$ from compounds $(\mathbf{b}, \mathbf{d}, \mathbf{f})$ on contact time with water (indices \#1, 2, 3 correspond to compounds containing actinides and REE).

Table 3. The leaching mechanism of components of the MKP compounds (indices \#1, 2, 3 correspond to the names of compounds containing actinides and REE).

\begin{tabular}{ccccc}
\hline $\begin{array}{c}\text { Components of } \\
\text { the MKP } \\
\text { Compounds }\end{array}$ & Correspond Figure & $\begin{array}{c}\text { Contact Time of } \\
\text { the Samples with } \\
\text { Water, Days }\end{array}$ & Slope of the Lines & $\begin{array}{c}\text { Leaching } \\
\text { Mechanism }\end{array}$ \\
\hline U_\#1 & $3 b$ & $1-7$ & 0.80 & dissolution \\
& diffusion \\
U_\#3 & 3b & $7-28$ & 0.55 & dissolution \\
depletion \\
La_\#2 & 3d & $1-10$ & 1.12 & dissolution \\
Nd_\#3 & 3d & $1-14$ & 0.06 & depletion \\
Am_\#3 & 3f & $14-28$ & 0.68 & diffusion \\
Pu_\#3 & 3f & $1-28$ & 0.54 & diffusion \\
dissolution \\
diffusion
\end{tabular}

\section{Discussion}

\subsection{Phase Composition and Structure of MKP Compounds}

The base of all the studied samples of compounds is the crystalline phosphate phase-the synthetic analogue of the K-struvite natural mineral $\mathrm{MgKPO}_{4} \times 6 \mathrm{H}_{2} \mathrm{O}$ (the characteristic peaks at 4.26, 4.14, 2.91, $2.70 \AA$ ) (Figure $1 \mathrm{a}-\mathrm{c}$ ). In this case, compound \#1 also contains a significant amount of the hydrated potassium uranyl orthophosphate phase, the X-ray diffraction parameters, of which correspond to the metaankoleite mineral $\mathrm{K}\left(\mathrm{UO}_{2}\right) \mathrm{PO}_{4} \times 3.0 \mathrm{H}_{2} \mathrm{O}$ (the characteristic peaks at 8.90, 3.75, 3.49 $\AA$ ) (Figure 1a). This is confirmed by the results of calculating the compound \#1 phase composition, according to the microanalysis data: the uranium-enriched particles (denoted by $\mathrm{M}$ in Figure 2a) contain up to $45 \mathrm{wt} \%$ of uranium and have an average composition $\mathrm{Mg}_{0.33} \mathrm{~K}\left(\mathrm{UO}_{2}\right)_{0.67} \mathrm{PO}_{4} \times 4.0 \mathrm{H}_{2} \mathrm{O}$, which corresponds to a mixture of metaankoleite $\mathrm{K}\left(\mathrm{UO}_{2}\right) \mathrm{PO}_{4} \times 3.0 \mathrm{H}_{2} \mathrm{O}$ and the $\mathrm{K}$-struvite $\mathrm{MgKPO}_{4} \times 6.0 \mathrm{H}_{2} \mathrm{O}$ in a molar ratio of $2 / 1$. In this case, the main phase of compound \#1 (phase KS in Figure 2a) contains up to 3 wt $\%$ of uranium.

As a result of potassium replacement with metals of nitric acid solutions, the $\mathrm{KNO}_{3}$ (niter) phase (the characteristic peaks at 3.78, 3.74, 3.04 $\AA$ ) is formed in the obtained compounds (Figure 1), 
which were also shown previously in $[9,10]$. However, it was not possible to identify this phase in compound \#1 (Figure 1a) by XRD method, probably because of its small content (theoretically not more than $5 \mathrm{wt} \%$ ), but its presence is clearly confirmed by microanalysis data (phase $\mathrm{N}$ in Figure $2 \mathrm{~b}$ ). Impurities of magnesium, phosphorus, and uranium in phase $\mathrm{N}$ (Figure $2 \mathrm{~b}$ ) do not exceed 0.6, 1.4, and $1.3 \mathrm{wt} \%$, respectively.

According to XRD (Figure 1b) and SEM ( $R$ in Figure 2c,d), it was established that lanthanum as REE in compound \#2 is present as a phosphate compound of the analogue of the natural mineral rhabdophane- $(\mathrm{La}) \mathrm{LaPO}_{4} \times 0.5 \mathrm{H}_{2} \mathrm{O}$. In this case, according to the microanalysis data, the main phase of compound \#2 (phase KS Figure 2c) is a phosphate compound of the composition $\mathrm{Mg}_{0.60} \mathrm{~K}_{0.68} \mathrm{La}_{0.36} \mathrm{PO}_{4} \times 6.3 \mathrm{H}_{2} \mathrm{O}$, similar to K-struvite. In compound \#2, the presence of the $\mathrm{KNO}_{3}$ phase ( $\mathrm{N}$ in Figure $2 \mathrm{c}$ ) is also clearly confirmed by SEM data.

The $\mathrm{MgO}$ (periclase) phase (the characteristic peak at $2.11 \AA$ ) is present in all of the studied compounds (Figure 1), and it is associated with an excess of the $10 \mathrm{wt} \%$ used $\mathrm{MgO}$ relative to the stoichiometry of the reaction (1) in accordance with the technique [10].

\subsection{The Leaching Rate and Mechanism of Actinides and REE from MKP Compounds}

The leaching rate of all metals decreases depending on the contact time of the studied compounds with water (Figure 3a,c,e). However, a significant difference in the rate of uranium leaching from compounds \#1 and \#3 was established: At the 28th day, the differential uranium leaching rate is $5.5 \times 10^{-7}$ and $4.4 \times 10^{-4} \mathrm{~g} /\left(\mathrm{cm}^{2}\right.$.day), respectively (Figure 3a). It was determined by XRD and SEM (Figures 1a and 2a) that uranium in compound \#1 is bound in a slightly soluble phosphate, which is analog of the natural mineral metaankoleite [24,25], which provides a high resistance of compound \#1 to uranium leaching. Obviously, the formation of such stable phase did not occur under the high-salt HLW surrogate solution solidification in compound \#3, due to the presence of a large amount of nitrates of various metals (salt background-369.5 $\mathrm{g} \cdot \mathrm{L}^{-1}$ ).

Data on the uranium leaching mechanism from compounds \#1 and \#3 (Figure 3b, Table 3) confirm the difference in leaching behavior. The logarithmic dependence of the uranium yield from compound $\# 1$ on the time of contact with water can be divided into two sections, which are described by linear equations with the slopes are 0.80 and 0.55 for seven days from the beginning of the test and the next 21 days, respectively. Thus, the uranium leaching mechanism varies depending on the duration of contact of the compound with water. So, during the first seven days, uranium leaching occurs due to surface dissolution of the compound, where individual particles of hydrated uranyl nitrate were localized. In the next 21 days, the uranium leaching is precisely determined by the diffusion transport from the inner layers of the compound. The uranium leaching from compound \#3 in the first 10 days, is determined by the intensive surface dissolution, which is probably enriched by uranyl nitrate, and in the next 18 days-due to the gradual surface depletion (the slopes are 1.12 and 0.06 , respectively).

The leaching rate of trivalent REE from the MKP compound increases with the increasing of content of various salts in the compound (for example, lanthanum and neodymium, Figure 3c). So, for compounds \#2 and \#3 the differential leaching rate of REE on the 28th day is $4.1 \times 10^{-6} \mathrm{~g} /\left(\mathrm{cm}^{2}\right.$. day) for lanthanum from compound $\# 2$, and $2.4 \times 10^{-5} \mathrm{~g} /\left(\mathrm{cm}^{2}\right.$. day) for neodymium from compound \#3. It is obvious (Figure 3d) that, under the contact of compound \#2 with water, the lanthanum leaching rate will decrease, since lanthanum leaching for 14 days is probably due to the surface dissolution (slope $=0.68$ ) of soluble lanthanum forms of compound \#2 in consequence of significant its content in the compound ( $6.2 \mathrm{wt} \%)$, and after 14 days by surface depletion (slope $=-0.39$ ). It is important to note that the neodymium leaching from compound \#3 is uniquely determined by diffusion from the inner layers of the compound (slope $=0.54$ ), which probably contains a uniformly distributed phase of hydrated neodymium nitrate that is unbound in slow-soluble phosphate forms.

The ${ }^{239} \mathrm{Pu}$ leaching rate is the main criterion of matrix quality evaluation for HLW immobilization. It has been established that compound \#3 reliably kept both plutonium and americium: the differential 
leaching rate of ${ }^{239} \mathrm{Pu}$ and ${ }^{241} \mathrm{Am}$ on the 28 th day is $3.5 \times 10^{-7}$ and $5.3 \times 10^{-7} \mathrm{~g} /\left(\mathrm{cm}^{2} \cdot\right.$ day $)$, respectively (Figure 3e). The plutonium yield from compound \#3 in the leaching agent in the first 10 days occurred under the surface dissolution of the compound (slope $=0.96$ ), and then by diffusion transport (slope $=0.41$, Figure 3f). Americium leaching is also determined by diffusion transport (slope $=0.54$ ), which is probably from the slow-soluble mixed orthophosphate (Am, $\mathrm{REE}) \mathrm{PO}_{4}$, which is an analogue of the natural mineral monazite.

The established low value of the ${ }^{239} \mathrm{Pu}$ leaching rate from MKP compound is close to the standard requirements for the glass-like compound for HLW immobilization $\left(1 \times 10^{-7} \mathrm{~g} /\left(\mathrm{cm}^{2} \cdot\right.\right.$ day $\left.)\right)$. However, it is important to note that MKP compound is synthesized at room temperature, whereas vitrification requires the use of expensive high-temperature electric furnaces or special melters, the liquidation of which after the end of the service life is a great radioecological problem, which is yet unsolved. Thus, the MKP compound approbation for immobilization of real wastes samples that were obtained by radiochemical plants during reprocessing of SNF, and a systematic comparison of MKP and glass-like compound quality indicators, including taking into account the technical and the economic evaluation of these technologies, are of scientific interest.

\section{Conclusions}

As a result of the research, it was established that MKP compounds that were synthesized at room temperature under solidification of nitric acid solutions, which are the surrogate solution of LRW, having complex chemical composition and containing actinides and REE, consisting of crystalline phases-analogues of natural phosphate minerals and possess high hydrolytic stability. Thus, the MKP compound is promising for the immobilization of LRW and it can be an alternative material combining the advantages of technology implementation simplicity that is similar to cementation and high physical and chemical stability corresponding to the glass-like compound.

Author Contributions: S.E. Vinokurov and B.F. Myasoedov conceived and designed the experiments; S.E. Vinokurov and S.A. Kulikova performed the experiments; S.E. Vinokurov, S.A. Kulikova and B.F. Myasoedov wrote the paper.

Funding: The research was funded by the Russian Science Foundation (No 16-13-10539).

Acknowledgments: Determination of element concentrations in solutions by ICP-MS and ICP-AES was performed at the Laboratory of Methods for Investigation and Analysis of Substances and Materials, Vernadsky Institute of Geochemistry and Analytical Chemistry, RAS (A.V. Zhilkina, I.N. Gromyak).

Conflicts of Interest: The authors declare no conflict of interest. The founding sponsors had no role in the design of the study; in the collection, analyses, or interpretation of data; in the writing of the manuscript, and in the decision to publish the results.

\section{References}

1. Ojovan, M.I.; Lee, W.E. An Introduction to Nuclear Waste Immobilisation, 2nd ed.; Elsevier: Amsterdam, The Netherlands, 2014; pp. 1-362, ISBN 978-0-08-099392-8.

2. Stefanovsky, S.V.; Yudintsev, S.V.; Vinokurov, S.E.; Myasoedov, B.F. Chemical-technological and mineralogical-geochemical aspects of the radioactive waste management. Geochem. Int. 2016, 54, 1136-1156. [CrossRef]

3. Stefanovsky, S.V.; Stefanovskaya, O.I.; Vinokurov, S.E.; Danilov, S.S.; Myasoedov, B.F. Phase composition, structure, and hydrolytic durability of glasses in the $\mathrm{Na}_{2} \mathrm{O}-\mathrm{Al}_{2} \mathrm{O}_{3}-\left(\mathrm{Fe}_{2} \mathrm{O}_{3}\right)-\mathrm{P}_{2} \mathrm{O}_{5}$ system at replacement of $\mathrm{Al}_{2} \mathrm{O}_{3}$ by $\mathrm{Fe}_{2} \mathrm{O}_{3}$. Radiochemistry 2015, 57, 348-355. [CrossRef]

4. Ewing, R.C.; Lutze, W.F. High-level nuclear waste immobilization with ceramics. Ceramics Int. 1991, 17, 287-293. [CrossRef]

5. Schlenz, H.; Neumeier, S.; Hirsch, A.; Peters, L.; Roth, G. Phosphates as safe containers for radionuclides. In Highlights in Applied Mineralogy; Heuss-Aßbichler, S., Amthauer, G., John, M., Eds.; De Gruyter: Munich, Germany, 2017; pp. 171-196, ISBN 9783110497342.

6. Schlenz, H.; Heuser, J.; Neumann, A.; SchmitzI, S.; Bosbach, D. Monazite as a suitable actinide waste form. Z. Kristallogr. Cryst. Mater. 2013, 228, 113-123. [CrossRef] 
7. Wagh, A.S. Chemically Bonded Phosphate Ceramics: Twenty-First Century Materials with Diverse Applications, 2nd ed.; Elsevier: Amsterdam, Netherlands, 2016; pp. 1-422, ISBN 978-0-08-100380-0.

8. Roy, D.M. New Strong Cement Materials: Chemically Bonded Ceramics. Science 1987, 235, $651-658$. [CrossRef] [PubMed]

9. Vinokurov, S.E.; Kulikova, S.A.; Krupskaya, V.V.; Danilov, S.S.; Gromyak, I.N.; Myasoedov, B.F. Investigation of the leaching behavior of components of the magnesium potassium phosphate matrix after high salt radioactive waste immobilization. J. Radioanal. Nucl. Chem. 2018, 315, 481-486. [CrossRef]

10. Vinokurov, S.E.; Kulikova, S.A.; Krupskaya, V.V.; Myasoedov, B.F. Magnesium Potassium Phosphate Compound for Radioactive Waste Immobilization: Phase Composition, Structure, and Physicochemical and Hydrolytic Durability. Radiochemistry 2018, 60, 70-78. [CrossRef]

11. Myasoedov, B.F.; Kalmykov, S.N.; Kulyako, Y.M.; Vinokurov, S.E. Nuclear fuel cycle and its impact on the environment. Geochem. Int. 2016, 54, 1156-1167. [CrossRef]

12. Vinokurov, S.E.; Kulyako, Y.M.; Slyunchev, O.M.; Rovny, S.I.; Myasoedov, B.F. Low-temperature immobilization of actinides and other components of high-level waste in magnesium potassium phosphate matrices. J. Nucl. Mater. 2009, 385, 189-192. [CrossRef]

13. Vinokurov, S.E.; Kulyako, Y.M.; Slyunchev, O.M.; Rovnyi, S.I.; Wagh, A.S.; Maloney, M.D.; Myasoedov, B.F. Magnesium potassium phosphate matrices for immobilization of high-level liquid wastes. Radiochemistry 2009, 51, 65-72. [CrossRef]

14. Wagh, A.S.; Sayenko, S.Y.; Shkuropatenko, V.A.; Tarasov, R.V.; Dykiy, M.P.; Svitlychniy, Y.O.; Virych, V.D.; Ulybkina, E.A. Experimental study on cesium immobilization in struvite structures. J. Hazard. Mater. 2016, 302, 241-249. [CrossRef] [PubMed]

15. Wagh, A.S.; Strain, R.; Jeong, S.Y.; Reed, D.; Kraus, T.; Singh, D. Stabilization of Rocky Flats Pu-contaminated ash within chemically bonded phosphate ceramics. J. Nucl. Mater. 1999, 265, 295-307. [CrossRef]

16. Singh, D.; Mandalika, V.R.; Parulekar, S.J.; Wagh, A.S. Magnesium potassium phosphate ceramic for ${ }^{99} \mathrm{Tc}$ immobilization. J. Nucl. Mater. 2006, 348, 272-282. [CrossRef]

17. Graeser, S.; Postl, W.; Bojar, H.-P.; Berlepsch, P.; Armbruster, T.; Raber, T.; Ettinger, K.; Walter, F. Struvite-(K), $\mathrm{KMgPO}_{4} \cdot 6 \mathrm{H}_{2} \mathrm{O}$, the potassium equivalent of struvite - a new mineral. Eur. J. Miner. 2008, 20, 629-633. [CrossRef]

18. GOST R 52126-2003. Long Time Leach Testing of Solidified Radioactive Waste Forms; Gosstandart of Russia: Moscow, Russia, 2003; pp. 1-8.

19. De Groot, G.J.; van der Sloot, H.A. Determination of leaching characteristics of waste materials leading to environmental product certification. In Stabilization and Solidification of Hazardous, Radioactive and Mixed Wastes: 2nd Volume; Gilliam, T.M., Wiles, C.C., Eds.; ASTM International: West Conshohocken, PA, USA, 1992; Volume 2, pp. 149-170. [CrossRef]

20. Torras, J.; Buj, I.; Rovira, M.; de Pablo, J. Semi-dynamic leaching tests of nickel containing wastes stabilized/solidified with magnesium potassium phosphate cements. J. Hazard. Mater. 2011, 186, 1954-1960. [CrossRef] [PubMed]

21. Al-Abed, S.R.; Hageman, P.L.; Jegadeesan, G.; Madhavan, N.; Allen, D. Comparative evaluation of short-term leach tests for heavy metal release from mineral processing waste. Sci. Total Environ. 2006, 364, 14-23. [CrossRef] [PubMed]

22. Moon, D.H.; Dermatas, D. An evaluation of lead leachability from stabilized/solidified soils under modified semi-dynamic leaching conditions. Eng. Geol. 2006, 85, 67-74. [CrossRef]

23. Xue, Q.; Wang, P.; Li, J.-S.; Zhang, T.-T.; Wang, S.-Y. Investigation of the leaching behavior of lead in stabilized/solidified waste using a two-year semi-dynamic leaching test. Chemosphere 2017, 166, 1-7. [CrossRef] [PubMed]

24. Gallagher, M.J.; Atkin, D. V-Meta-ankoleÏte, hydrated potassium uranyl phosphate. Bull. Geol. Soc. Great Britain. 1966, 25, 49-54.

25. Fleischer, M. New mineral names. Am. Miner. 1967, 52, 559-564.

(C) 2018 by the authors. Licensee MDPI, Basel, Switzerland. This article is an open access article distributed under the terms and conditions of the Creative Commons Attribution (CC BY) license (http:/ / creativecommons.org/licenses/by/4.0/). 